\title{
Towards a Democratic Developmental State
}

\section{Gordon White*}

'In Third World conditions, Western-style democracy is as much use as a three-piece suit in the desert.' (anonymous Sudanese military official)

\section{Introduction}

If the 1980s saw the rise of a new orthodoxy about the developmental role of states, the early 1990s have seen the rise of a new orthodoxy about the developmental role of political regimes. The former criticised the developmental states of the postcolonial era for excessive economic dirigisme, advocating a reduction in their role and a freeing up of markets and private enterprise along neo-liberal lines. The latter extended this to a critique of political dirigisme, emphasising the developmental deficiencies of authoritarian regimes as well as their denial of human rights and civil freedoms and advocating a transition to democracy along liberal lines. By the mid-1990s, these two critiques have coalesced into a comprehensive strategic vision of both political and economic probity, according to which development can best be promoted through a market-friendly state presiding over a predominantly capitalist economy operating within the political 'shell' of a liberal democratic polity.

The economic and political components of this vision are logically interconnected: markets and private enterprise provide the basis for political pluralism and the institutionalised limits which the liberal polity imposes on the concentration of political power serve to curb any tendency towards economic dirigisme. The parameters of 'sound' developmental action are thus transformed and narrowed: in economic terms, the developmental state of the 1960s and 1970s becomes an anachronism to be replaced by a state whose functions are primarily regulatory; in political terms, regime options are reduced to a model of liberal democracy defined primarily in conventional procedural terms. ${ }^{1}$

Alternatives are not only not advisable but are also not feasible, not least because liberal politics and economics at the national level are embedded within, and reinforced, by a global system in which markets reign supreme and the political atmosphere favours the extension and perpetuation of democratic regimes.

This image of developmental correctness is grossly unexamined and begs a lot of fundamental questions. As a model of economic development it is riddled with contradictions and susceptible to the same kind of criticisms which were levelled against growthoriented conceptions of development in the late 1960 s by Dudley Seers and Hans Singer among others. This article is about the political economy of this strategy, specifically the relationships between political and economic variables that it envisages and their implications for development. My analysis is based on two basic assumptions: first, that many countries in the erstwhile Second and Third Worlds are yet to make the developmental transition in socioeconomic terms and the countries that have done this definitively (such as the East Asian NICs newly industrialised countries) are still relatively few; and, second, that the process of development involves more than just economic growth but also life-and-death issues of poverty, personal security, distributive equity, social justice and environmental sustainability. The tsunami of democratisation over the past decade has brought liberal democratic institutions to numerous countries which still face this developmental challenge. ${ }^{2}$ Will this change in political regime improve the capacity of developing societies to tackle it effectively? 
At first glance, one is inclined towards scepticism. Economic historians tell us that many of the early wave of successful developers, such as Japan, Germany and Russia, did so under political circumstances that could hardly be called democratic; that in the great forerunner, the UK, the developmental breakthrough preceded democratisation; and, more recently, that the exceptional developmental successes of East Asia were all achieved under authoritarian auspices. Recent cases of successful developmental transition under democratic regimes are hardly legion (Botswana, of course, and Mauritius) and, while it is evident that many of the authoritarian developmental states of the post-colonial era have been egregiously unsuccessful, this is not in itself evidence that a change of regime would make a positive difference. While it is currently convenient to attribute their lack of success to predatory elites, it should also be pointed out that they were also undermined by the character of the societies in which they were embedded and overwhelmed by the developmental constraints and challenges they faced, both domestically and internationally. As with their democratic counterparts, authoritarian regimes also need certain 'preconditions' to be politically authoritative and developmentally effective; if these have been lacking, then their democratic successors may well run up against the same problems with the same debilitating political and economic consequences. But even if we assume for the moment that new democratic regimes can be consolidated, does democracy make a developmental difference and if so, how?

\section{Democracy and development: some variant views}

While it is common to find Western politicians and political commentators on development waxing eloquent about the positive developmental consequences of democratisation, there is by no means a consensus on the issue among development professionals and analysts. First, there is an optimistic view, common among aid circles (particularly in Western national aid agencies and international institutions), that liberal democracy is a powerful stimulus to development, basically because it provides a more conducive environment for market-led economic development and because it carries the potential for more efficient and accountable government. ${ }^{3}$ Though this optimistic view is most commonly found among liberals and neo-liberals, it is also shared, albeit in a different form and for different reasons, by people across a much wider political spectrum, including democratic socialists and advocates of participatory development who see democracy as opening spaces for developmentally positive forms of popular mobilisation.

Particularly in societies with recent histories of autocratic, incompetent or corrupt authoritarian regimes, this view has obvious attractions, but as a general proposition the case is somewhat shaky. First, while it may be true that there is a long-term statistical correlation between democracy and prosperity, this says little about their causal relationships in the short and medium terms, particularly in the earlier stages of development. Moreover, even if it were true, as The Economist claims, that 'far from inhibiting growth, democracy promotes it', there is still the question of what kind of growth and what sort of implications it has for a broader conception of development. Second, the empirical evidence used to support the case has so far proven far from convincing; indeed there has been a tendency to use empirical data like the proverbial drunk uses the lamp-post - for support rather than illumination. ${ }^{4}$ Third, there is a tendency to emphasise the potential benefits of an idealised conception of democratic process rather than to base analysis on the ways in which democracies actually do operate in poor societies - which are often far from the ideal type. (For vivid evidence on this, see O'Donnell 1993 on Latin America and Nicro 1993 on Thailand.)

Second, there is a pessimistic view which regards democracy as a valuable long-term goal but a potential impediment to the earlier stages of development. In other words, democracy is a luxury which poor societies can ill afford. This view is more popular among Third World officials who would agree with Singapore's Lee Kuan Yew when he states that 'I believe that what a country needs to develop is discipline more than democracy. The exuberance of democracy leads to indiscipline and disorderly conduct which are inimical to development'. ${ }^{5}$ The view receives more detached support from social scientists: for example, Leftwich (1993: 13) argues that 'if the primary developmental objective is the defeat of poverty and misery, then liberal or pluralist democracy may also not be what many Third World or Eastern European countries need or can sustain in their present conditions'. This pessimism is also shared to some extent by supporters of democracy who do not 
expect much from procedural democracy at the national level and therefore concentrate on a 'bottom-up' micro-strategy based on the democratising and developmental potential of grassroots and community organisations. For example, Landell-Mills (1992: 10) argues that liberal democracy will not necessarily lead to economic growth, or alleviation of poverty, or protection of the weak, or efficient government. In his view, a strong civil society must be developed to achieve more accountable government; but even then, it is 'perhaps not wise government'.

Pessimists tend to list a number of seemingly insuperable post-transitional obstacles which Huntington (1991: 209-10) conveniently groups into two categories, contextual and systemic. The former stem from the nature of the particular society and the developmental problems it faces; the latter from the characteristic ways in which liberal democratic polities operate. Contextual problems tend to smother the political system with excessive demands resulting from a 'tide of rising expectations' and undermine its capacity to process these demands. Systemic problems derive from the institutionalised uncertainty, instability and conflict inherent in democratic politics. ${ }^{6}$ Both these sets of problems can lead to political fluctuation, paralysis or disorder which weaken the capacity of democratic governments to shoulder the developmental burden, whether this is defined in narrower regulative or broader interventionist and redistributive terms. By contrast, the experience of the 'rational authoritarianism' of the 'four tigers' of East Asia is cited as evidence of a developmentally desirable and politically appropriate kind of alternative.

However, even four swallows do not make a spring and the dismal deficiencies of most forms of authoritarianism outside East Asia weakens any general case for authoritarianism per se as a political recipe for developmental success. Authoritarian polities have their own systemic problems as developmental agents, such as rigidity, corruption and rent-seeking, or excessive concentration of political and economic power, in addition to the human costs they impose through repression or denial of civil rights. Indeed, in many countries the impetus towards democratisation has been fuelled by the demonstrated developmental failure of authoritarian regimes. In this context, the pragmatic case for 'trying out' the democratic alternative is compelling. Perhaps the most we can grant to the 'rational authoritarian' argument is that, where a non-liberal democratic regime demonstrates a clear capacity to cope effectively with developmental problems and is not engaged in gross violations of the civil rights and personal security of its citizens, it should not be pushed willy-nilly into a wholesale and immediate adoption of a liberal-democratic polity.

The third view on the relationship between democracy and development is what one might call the 'don't expect anything' school. Huntington, for example, argues that the sustainability of a stable democracy depends on 'disillusionment and lowered expectations' on the part of the general population. Furthermore, 'Democracies become consolidated when people learn that democracy is a solution to the problem of tyranny, but not necessarily to anything else' (1991: 263). This kind of view is buttressed by the argument that democratic regimes are not legitimised by their performance but by their procedures, ${ }^{7}$ whereas it is one of the inherent weaknesses of authoritarian regimes that they have to derive their legitimacy from their performance and are thus vulnerable to economic downturns. Thus inflation over 20 per cent per annum might shake the foundations of the entire Communist regime in China, whereas in a democratic context this might threaten the government of the day, but not the regime.

This kind of argument may make some sense in countries which have already achieved a relatively high level of economic development and still retain a growth momentum. But it does not cut much ice in the context of countries faced by a combination of extreme poverty and massive inequalities on the one hand and accelerating popular expectations fuelled by the international demonstration effect on the other. As Huntington himself (1991: 258) points out, new democracies face a Catch-22 situation because 'lacking legitimacy, they cannot become effective; lacking effectiveness, they cannot develop legitimacy'. A good deal of the political impetus behind democratic transition in a country such as Zambia, for example, was the result of popular disillusionment with the growth performance of the previous regime, not necessarily its political character In such circumstances, it is probably unrealistic to assume that populations will lower their expectations of the political system and be content with the specific gains, important though they may 
be, which derive from democratic guarantees and rights. We should add, moreover, that the argument that the legitimacy of democratic regimes rests on their procedures rather than their performance applies primarily to consolidated democracies indeed it is one of the hallmarks of democratic maturity. As Diamond (1992: 35) points out, 'democracy becomes truly stable only when people come to value it widely not solely for its economic and social performance but intrinsically for its political attributes'. As such, the argument has little relevance to countries where democracies are still struggling to consolidate themselves in highly inimical socioeconomic contexts.

A fourth position on the relationship between democracy and development is that the nature of the political regime is not the central issue; rather it is good governance and state capacity, qualities which can be developed under different types of regime. In the context of sub-Saharan Africa, for example, Jeffries argues that 'the current moves towards multi-party democracy are, relatively speaking, an irrelevance' (1993: 30) and the first priority should not be regime change but 'improving the capacity, commitment and quality of government administration, of developing an effective developmental state' (ibid.: 28). He cites the regimes of Raulings in Ghana and Museveni in Uganda as examples of 'relatively non-corrupt, economically responsible and effectively reforming authoritarian regimes' and questions whether they should have been put under pressure to convert to multi-party democracies. In essence, the argument here is for the primacy of constructing an effective developmental state, whether by authoritarian or democratic means.

This argument contains much of substance, but is open to question on several counts. Cases of authoritarian regimes capable of 'good governance' are relatively few. But even in these cases, the issue of political regime is not irrelevant. Such 'rational' authoritarian regimes have costs in terms of their autocratic behaviour, denial of civil rights and repression of dissent. Moreover, one can argue that it is exactly this kind of political and administratively successful regime that is most ripe and ready for democratisation, even if we accept Jeffries' point that the transition should not be brought about through a pressured and precipitate transition to multi-partyism. Casting our net more widely, however, most authoritarian regimes in Africa and elsewhere may have laid claim to the title of 'developmental state', but have been singularly unsuccessful in establishing a capacity for good governance and developmental efficacy. In such cases, a change in political regime may be highly relevant as an alternative way of achieving an 'effective developmental state'. Moreover, we should take heed of the optimists who argue that certain of the central characteristic features of liberal democracies - selection of political leaders through elections, open and unfettered competition for political office and the pressures exerted by a free press and public opinion - are essential mechanisms for creating a state which is responsive, efficient and accountable. In situations where authoritarian regimes have failed (as in much of sub-Saharan Africa) or been superseded (as in much of East Asia and Latin America), the question of the relationship between democracy and development should be put in more positive terms: to what extent and in what ways can the parallel priorities of a democratic political system and an effective developmental state be achieved in tandem? Can developmental democracy be 'crafted' or 'designed'? This is the main theme of the rest of this article.

\section{How to construct a democratic developmental state: approaching the issue}

The analysis which follows rests on several basic propositions. First, democracy, even in its procedural or minimalist form, is a massive developmental good in its own right. By contrast, even the most 'rational' forms of authoritarianism have not been valued for themselves (among the development community, at least), but regarded as undesirable means towards desirable developmental ends which could be dispensed with when their unpleasant, but historically essential, task was completed. In this light, any arguments couched merely in terms of the relative virtues of authoritarianism versus democracy as alternative means for achieving development are miscast. $A$ broad consensus has formed around this idea, extending to include the radical left, partly because the Leninist alternative has collapsed and partly because it never delivered much in the way of democracy in any case. Democratic socialists of course seek to extend the notion of democracy outside the polity into the society and economy, but they are now much more willing to recognise the inherent virtues of the standard model of liberal democracy. ${ }^{8}$ That said, however, there are certain potential trade-offs and incompatibilities between 
democracy and development which must be addressed and minimised where feasible.

Second, in the foreseeable future at least, a combination of domestic and international pressures are likely to maintain many of the new democratic regimes in operation, even if at 'low intensity' levels. ${ }^{9}$ This makes arguments about the relative developmental advantages of authoritarianism versus democracy irrelevant in those societies where an authoritarian alternative is not on the cards.

However, it does give urgency to questions about how to add substance to democratic institutions in societies where they are superficially implanted and how to improve their developmental potential. The activities of external agents - whether international institutions, national donors or foreign nongovernmental organisations (NGOs) - can influence this process for good or ill, depending on the motives for intervention and the skill with which it is exercised.

Third, for fledgling democracies to be consolidated and existing 'low-intensity' democracies to be deepened, effective developmental performance is essential to avoid the Catch-22 identified by Huntington. If the socioeconomic preconditions of democracy do not exist, they have to be created along with the construction of democracy itself. Effective developmental performance covers a broad spectrum of governmental action - including economic growth, social and physical investment and redistribution - not merely because these are desirable in themselves, but also because they are necessary to the consolidation and deepening of democracy. The key issue is how to construct a virtuous circle between socioeconomic development on the one hand and political development on the other. By 'political development' here we mean both the construction of efficient and accountable public institutions and the spread of real as opposed to titular democratic citizenship and enfranchisement through an increasingly pervasive process of social empowerment.

Fourth, the future of both development and democracy depends on the ability of a society to construct an effective developmental state. Democratisation without a serious effort to reform and/or strengthen the state may mean that a diversification of political elites through multi-party competition will just mean more snouts in the trough and successful private sector development will just mean fattening more frogs for snakes. The democratic developmental state will need to have a broad writ with at least three basic socioeconomic functions: regulative, infrastructural and redistributive..$^{10}$ It will also need sufficient political authority and administrative capacity to manage the social and political conflicts arising both from the persistence of 'primordial ties' and from the tensions inherent in a successful growth process.

Fifth, the construction of the democratic developmental state entails not only the pursuit of 'good governance' but also 'good politics' in the sense that the process goes beyond the creation of sound public institutions to include the character of political society, the relations between polity and society, and the political role of organised groups in civil society. ${ }^{11}$ Thus the narrow framework within which conventional development discourse discusses these problems needs to be greatly expanded and a wider range of political issues needs to be addressed explicitly. The common tendencies to discuss 'politics' circumlocuitously through coded language or to avoid 'politics' altogether by concentrating on issues of 'administrative reform' or 'governance' may be bureaucratically convenient, but they are intellectually (and ultimately practically) counterproductive.

Sixth, a combination of internal and external contextual factors, the latter including the volatile nature of the international financial system and fluctuations in international patterns and terms of trade, may make the task of developing both democratic and developmental effectiveness very difficult. As economies become more open and porous, they become less autonomous and the freedom of action of domestic decision-makers is reduced accordingly. The notion of sovereignty which underlies democratic authority and accountability is thereby undermined, with potentially explosive consequences. ${ }^{12}$

\section{Developmental democracy by design? Potential arenas of action}

In exploring the possibilities for 'designing' a state which is both democratic and developmental, it is useful to see 'democratisation' not as a relatively sudden rupture of regime transition, but as a process of institutional accumulation, built up gradually like layers of coral. We draw here on Richard Sklar's 
notion of 'developmental democracy'. In his conception, 'Democracy comes to every country in fragments or parts; each fragment becomes an incentive for the addition of another' and he stresses the need for 'political invention and improved design' of democratic institutions to confront the problems of development (1987: 714). From this perspective, the contemporary developmental democrat is a modern Machiavelli who is constantly seeking to reconcile the democratic and developmental imperatives through conscious, incremental institutional adaptation.

Now we are emerging from the manichean world of the Cold War which tended to reproduce a homogenised image of each of the two warring political systems, there is growing awareness of the institutional and processual variations among liberal democratic systems in the industrialised countries. There is concomitant awareness of the important variations in the character of capitalism in different societies. Each national form of democracy takes on its particular character in response to the specific character of the society in which it is embedded and the specific historical conditions under which it emerges. In the case of the industrialised countries, there are already attempts at typologies to capture this diversity. Winckler (1992: 253-4), for example, when inquiring into the particular form of democracy towards which Taiwan might evolve, argues that there are 'three basic alternatives: Japanese fiduciary statism, American interest pluralism, and European consultative elitism' and sees Taiwan's democratic trajectory as a shifting mix of all three forms. While this and other typologies are based on the industrialised countries, it is to be expected that other distinctive forms of democracy may well emerge in the developing world (just as, for example, in the economic realm one can talk of Korean-style or Chinese-style capitalism). ${ }^{13}$

If one can expect the forms and dynamics of liberal democracies to vary, the important question for our inquiry is whether there are particular forms of democracy which are more suited to tackling severe developmental challenges. Answers to this question will clearly vary across countries and an in-depth configurative approach will be necessary when one gets down to the brass tacks of institutional change in any one country. We can begin thinking about these issues in general terms, however, by identifying certain key arenas of potential institutional design.
As the above classification of three 'models' of democracy suggests, democracies differ not merely in the character of their political institutions, but also in the ways these interact with society. The organisation of state-society relations has two basic dimensions: first, the constitutionally defined realm of formal political, administrative and legal entities which set the institutional framework of a democratic regime and, second, the informal and formal organisations and channels which connect politicians, officials and agencies with social constituencies in 'civil society'. These could be called the 'exterior' and the 'interior' worlds of democratic politics. Brian Crisp, who has done detailed research on the latter in the Venezuelan context, calls these the 'electoral' and the 'consultative' arenas respectively and argues that democratic reform must involve both (1993: 1501). The 'interior' arena is particularly important in societies in which socioeconomic resources are highly unequal, since it is the context within which powerful elites can interact with their political and governmental counterparts and influence the policy process in their favour. If we are interested in the interaction between democratic institutions and developmental capacity, therefore, the 'consultative' arena should be a particular focus of attention, particularly if we are interested in extending political access and influence to a wider range of social groups.

As an initial attempt to impose some kind of analytical order on these complex and multidimensional processes, we can separate out three political terrains as potential arenas for institutional 'crafting': formal state institutions, political society and civil society. Let us discuss each in turn.

- The institutional design of the state. There is a range of institutional alternatives in designing political and governmental agencies which may, by their impact on the internal structure of the regime and its channels of communication and access to political and civil societies, affect its capacity for stable, coherent governance and developmental decision. This involves areas of traditional political engineering such as electoral systems, decentralisation and devolution of government, administrative reform, legal systems, division of powers (notably differences between presidential and parliamentary systems) and the nature of legislatures. Various questions suggest themselves if we are primarily interested in the 
extent to which specific institutional alternatives can improve a polity's capacity to tackle serious developmental issues. For example, what kind of voting system would increase the chances of producing more integrative political parties capable of providing programmatic alternatives and credible government? Will a presidential or a parliamentary system better enable democratic polities to grasp developmental policy nettles? ${ }^{14}$ Will decentralisation improve the responsiveness and accountability of government and, if so, in what forms? These elements of democratic polities are constant subjects of academic research and political debate in the industrialised countries, yet with a few exceptions (such as decentralisation) there has been comparatively little work on the new democracies.

\section{- The character of political society. Political}

society refers primarily to the nature of political parties which function as crucial links between citizens and governance. The conventional notion of democracy current in development circles includes a 'multi-party system' as a central defining element. But a consistent strand in thinking about the relationship between democracy and governance in the industrialised world, at least in Anglo-America, has been that 'multi' should ideally denote no more than two since a two-party system can combine the advantages of both political competition and stable governance, as opposed to multi-party systems which have to survive through shifting and often unstable coalitions which make the definition and implementation of long-term policies more difficult. One might go further and argue that the best potential underpinning for a developmentally effective polity is a one-party dominant system. Some of the most impressive democratic developmental performers over the past half century, notably Sweden and Japan and more recently Botswana, have had one-party dominant systems, which, in their cases at least, seem to have combined the best of both developmental and democratic worlds. The dominant party was subject to regular democratic tests at the ballot box and constantly subject to the pressures of a free civil society, while at the same time maintaining the coherence, authority and capacity for long-term decision-making which is necessary for tackling the structural problems of development. ${ }^{15}$ The post- authoritarian political elite in South Korea - with the Japanese precedent very much in their minds - has sought to forge just such a dominant-party system through the amalgamation of the former ruling party and part of the opposition parties, in an attempt to retain the previous developmental capacity of the state in the new democratic context.

\section{- The character and role of civil society. The}

nature and impact of democratic political institutions are heavily influenced by the character and behaviour of organised groups in 'civil society' their heterogeneity, their capacity to coalesce, and the nature of their relationships with the parties and state institutions. If we focus on the 'one-party dominant model', for example, these interrelations between the state, political society and civil society have taken two basic forms inclusive and exclusive - typified by Sweden and Japan. In the former, there is a broadly based 'social compact' involving an 'inclusive coalition' between the main segments of civil society, brokered and organised by the state and a dominant political party (in the Swedish case, this involved the Social Democratic Party, business and labour). In the latter, there is a pact of domination involving an alliance between state institutions, a dominant political party and a hegemonic section of civil society (in the Japanese case, the components have been the state bureaucracy, the Liberal Democratic Party and big business); something similar may be evolving in South Korea and Taiwan.

This area of discussion leads us naturally to the issue of corporatism as a specific way of organising the links between state, political society and civil society so as to create the political consensus, stability and capacity needed for longer-term developmental decision-making (e.g. Cheng and Krause 1992 advocate an explicitly corporatist model for South Korea). However, corporatist systems are notoriously difficult to establish and maintain (Bianchi 1986), particularly so in more heterogeneous and schismatic societies in which democratic rule, to be stable and effective, may need to organise the relationships between civil society, political society and the state in very different ways: for example, along the lines of 'consociational' democracies analysed by Lijphart (1968) or the kind of political subsidiarity which Parekh (1992) has argued as one of the fundamental 
underpinnings of stable democracy in India. Such solutions, while improving the developmental capacity of the national political system, may have problematic distributive and redistributive consequences if the dominant coalition, whether inclusive or exclusive, only includes a relatively narrow, and relatively influential, section of society, the remainder being weakly represented or unrepresented in the political process. Thus, such a macro-strategy of 'developmental democracy' could ideally be complemented by a micro-strategy, along the lines advocated by David Korten (1990) and Pierre Landell-Mills (1992), based on a commitment to associational mobilisation of politically marginalised groups which function both as an alternative developmental agency to the state and as a source of political pressure on the state.

\section{Some concluding remarks}

The above analysis has sought to suggest some new ways of thinking about the relationship between democracy and development and hopefully point the debate in a more positive and practical direction. It has raised more issues than it can answer, but with the intention of mapping out a preliminary agenda for a broad, comparative research programme on the intricate relationships between democracy and development. However, this preliminary mapping needs to be taken further before detailed research can commence. For example, the issues of feasibility and agency need to be systematically addressed. On the question of feasibility of institutional 'design' or 'crafting', to a considerable extent institutions rest on and are moulded by profound structural factors - the specific character of the social and economic structure, the dominant systems of cultural thought and behaviour, the specific impact of the state-based and international constellations of power, and the constitution of civil and political societies - which set, and often radically reduce, the room for political manoeuvre. On the question of agency, much of the analysis of the process of 'democratisation' in the sense of regime transition has emphasised the importance of human, particularly elite, agency in 'crafting' transitions at this crucial genetic phase of democratic polities. ${ }^{16}$ In such fluid and malleable situations, the parameters for institutional design and creativity may be relatively flexible. However, if we understand 'democratisation' in the longer-term sense of the consolidation and deepening of democratic institutions and predispositions, there is a 'settling in' process, like ships in the mud, whereby evolving institutions become increasingly embedded in the deeper structures of power and interest in society and become harder to change in consequence. To the extent that this is true, the role of what I would call 'positive' external conditionality - do this, or else - in constructing democratic developmental states is likely to be minimal, though 'negative' conditionality - don't do that, or else could still be applied to issues such as human rights abuse. On the other hand, there is a continuing role for external assistance in the process of institutional development, though this would need to be based on the demand or consent of the recipients and very carefully focused to avoid negative political consequences.

There is also a need to think systematically about the political dynamics of democracies in developing societies. First, it is important to seek a more precise understanding of their power dynamics - the extent to which different groups and interests gain access to political power in a democratic context and the resulting consequences for development policy. ${ }^{17}$ Understanding of political dynamics also requires analysis of the roles of the 'electoral' and 'consultative' arenas of political action and the relationship between real as opposed to formal 'citizenship'.18 These will help to generate greater awareness of the political coalitions behind institutional change in general and behind efforts to construct democratic developmental regimes in particular. Second, we need a more precise knowledge of their actual operating processes, particularly in the light of our growing awareness of the darker dynamics of 'advanced' democratic systems in Italy, France, the UK and Japan. How do democracies actually work in different social-economic-cultural contexts as opposed to how they are supposed to work - detailed studies of countries such as Thailand, Venezuela or the Philippines would be instructive in this regard. Third, to enable us to think more clearly about the potential synergy or trade-offs between development and democracy, it would be important to investigate the experience of societies where a democracy has gone hand in hand with a certain degree of developmental success (perhaps Botswana, Mauritius or Venezuela) and compare them with other societies where the presence of a democratic polity has been cited as an impediment to development (e.g. India). In addition, one could inquire into the impact of recent democratisation on the developmental capacity and performance of East 
Asian NICs such as South Korea and Taiwan and investigate how domestic political actors are trying to cope with the problems which arise.

Effective developmental performance is crucially important for the political future of the new democracies of the erstwhile Third World. While conditions over recent years have favoured their emergence, one should not be complacent about their future. If they are developmentally ineffective, a vicious downward spiral of mutually reinforcing

\section{Notes}

1 Huntington (1991: 7) uses the procedural notion when he argues that a polity is democratic 'to the extent that its most powerful collective decisionmakers are selected through fair, honest, and periodic elections in which candidates freely compete for votes and in which virtually all the adult population is eligible to vote'.

2 For an overview of the most recent wave of democratisation in the developing world, see Luckham and White (1975).

3 For a well-argued exposition of this position, see 'Democracy and Growth: Why Voting is Good for You', The Economist, 27 August 1994: 17-19.

4 For example, the reader is invited to see whether he/she is convinced by the evidence for the putative ability of democratic regimes to carry out sweeping programmes of economic reforms reported in the above article in The Economist, or the evidence adduced to support the judgement that 'democratisation promotes economic development' by Shin (1994: 156-7). For a review of statistical analyses of the relationship between democracy and development, see Moore (1975).

5 Cited in The Economist, 27 August 1994: 17.

6 For instance, Huntington (1991: 210) lists problems which 'tend to be peculiarly characteristic of democratic systems: stalemate, the inability to reach decisions, susceptibility to demagoguery, domination by vested economic interests'.

7 For example, Linz and Stepan (1989) make this argument in the South American context.

8 For an early 'socialist-revisionist' discussion of these issues in the African context, see Sandbrook (1988).

9 The idea of 'low-intensity democracy' is discussed in Gills, Rocamora and Wilson (1993).

10 By 'regulative' functions, we refer to the role of the state not only in ongoing macroeconomic management but also in constructing the economic and political decline may well set in. Moreover, if they continue to rest on vast inequalities and remain as oligarchic 'semi-democracies' operating largely in the interests of dominant elites, their role as agents of both democratisation and development will be severely circumscribed. If they are not successful in 'producing the goods', they will be prey to authoritarian reversals based on ideologies which thrive on the ideas that democratic polities are inherently corrupt, divisive, unstable or ineffectual.

institutional framework necessary for the functioning of complex market economies. By 'infrastructural' functions we refer to the process of creating both physical and social infrastructure, the latter pursued through growth-enhancing social policy and welfare provision. By 'redistributive' functions we refer to the need to tackle absolute poverty and ameliorate morally repugnant, economically unproductive and social destructive forms of severe inequality.

11 For a discussion of the ideas of 'political society' and 'civil society', see White (1994).

12 The relationship between democratic authority and national sovereignty in the context of the postCold War world order is discussed by Held (1993).

13 For an illuminating analysis of different forms of capitalism among the East Asian NICs, for example, see Whitley (1994).

14 O'Donnell (1992) discusses some of the pitfalls of presidentialism in the Latin American context.

15 For a comparison of 'one-party dominant regimes', see Pempel (1990); for a study of oneparty dominance in Botswana, see Molutsi and Holm (1990). Di Palma (1990) discusses the difficulties involved in establishing such systems and Ferdinand (1994) argues that the global dynamics of the post-Cold War era are undermining these systems. The recent experience of the Mexican PRI regime may be good evidence for his argument.

16 For a review of this literature, see Shin (1994: 38-41). To the extent that the institutional arrangements which emerge from these elitedefined transitions reflect the interests of these very elites, one of the most urgent, and developmentally crucial, elements of democratic consolidation is to improve the political access of wider sections of society and involve them in the process of institutional 'crafting'. In the history of 
Western societies, for example, the role of labour parties based on an organised working class played an important role in providing the political impetus for and designing the central features of their 'welfare states'.

17 For example, there is a potential conflict between a neo-liberal regulative strategy and a redistributive poverty-oriented strategy in terms of the power weightings behind each strategy which are actually revealed in the political process.

18 The extreme inequalities of most developing societies tends to mean that access to political

\section{References}

Bianchi, Robert (1986) 'Interest Group Politics in the Third World', Third World Quarterly 8.2 (April): 507-39

Cheng Tun-jen and Krause, L.B. (1992) 'Democracy and Development: With Special Attention to Korea', Journal of Northeast Asian Studies, (Summer): 3-25

Di Palma, Giuseppe (1990) 'Establishing Party Dominance: It Ain't Easy', in T.J. Pempel (ed.), Uncommon Democracies: The One-Party Dominant Regimes, London: Cornell University Press: 162-88 Diamond, Larry (1992) 'Introduction to Political Culture and Democracy in Developing Countries', manuscript, cited in Shin (1994) 'On the Third Wave of Democratization: A Synthesis and Evaluation of Recent Theory', World Politics 47.1 (October): 154

Ferdinand, Peter (1994) 'The Party's Over - Market Liberalization and the Challenges for One-party and One-party Dominant Regimes: The Cases of Taiwan and Mexico, Italy and Japan', Democratization 1.1 (Spring): 133-50

Gills, Barry, Rocamora, Joel and Wilson, Richard (eds) (1993) Low Intensity Democracy: Political Power in the New World Order, London: Pluto Press

Held, David (1991) 'Democracy, the Nation-state and the Global System', Economy and Society 20.2 (May): 138-72

Huntington, Samuel, P. (1991) The Third Wave: Democratization in the Late Twentieth Century, London: University of Oklahoma Press Jeffries, Richard (1993) 'The State, Structural Adjustment and Good Government in Africa', Journal of Commonwealth and Comparative Politics 31.1 (March)

Korten, David, C. (1990) Getting to the 21st Century: Voluntary Action and the Global Agenda, West Hartford: Kumarian Press power is seriously maldistributed, notwithstanding the countervailing influence of electoral politics. In power (and therefore policy) terms, in consequence, developing democracies tend to be characterised by a powerful 'core' dominated by well-resourced elites and a powerless 'periphery' of effectively disenfranchised citizens. To the extent that this is true in any given society, there would seem to be a case that a large proportion of external 'development aid' should be aimed at counter-balancing this structural asymmetry.

Landell-Mills, Pierre (1992) Governance, Civil Society and Empowerment in Sub-Saharan Africa: Building the Institutional Basis for Sustainable Development, Washington DC: World Bank, Africa Technical Department (10 June)

Leftwich, Adrian (1993) 'Voting Can Damage Your Wealth', The Times Higher Education Supplement, 13 August: 11-13

Lijphart, Arend (1968) 'Consociational Democracy', World Politics 21.1 (January): 207-25

Linz, Juan and Stepan, Alfred (1989) 'Political Crafting of Democratic Consolidation of Destruction: European and South American Comparisons', in R.A. Pastor (ed.), Democracy in the Americas, New York: Holmes and Meier

Luckham, Robin and White, Gordon (1975), Democratization in the South: The Jagged Wave, Cambridge: Cambridge University Press

Molutsi, Patrick, P. and Holm, John, D. (1990) 'Developing Democracy When Civil Society is Weak: The Case of Botswana', African Affairs 89 (356): 323-40

Moore, Mick (1975) 'Is Democracy Rooted in Material Prosperity?', in R. Luckham and G. White (eds), Democratization in the South: The Jagged Wave, Cambridge: Cambridge University Press

Nicro, Somrudee (1993) 'Thailand's NIC Democracy: Studying From General Elections', Pacific Affairs 66.2 (Summer): 167-82

O'Donnell, Guillermo (1993) 'On the State, Democratization and Some Conceptual Problems: A Latin American View With Glances at Some Post-communist Countries', World Development 21.8 (August): 1355-70

O'Donnell, Guillermo (1992) Delegative Democracy?, Working Paper 172 (March), Notre Dame: Kellogg Institute 
Parekh, Bhikhu (1992) 'The Cultural Particularity of Liberal Democracy', Political Studies XL: 160-75

Pempel, T.J. (ed.) (1990) Uncommon Democracies: The One-Party Dominant Regimes, London: Cornell University Press

Sandbrook, Richard, L. (1988) 'Liberal Democracy in

Africa: A Socialist-Revisionist Perspective',

Canadian Journal of African Studies 22.2: 240-67

Shin Doh Chull (1994) 'On the Third Wave of

Democratization: A Synthesis and Evaluation of

Recent Theory', World Politics 47.1 (October): 135-70

Sklar, Richard, L. (1987) 'Developmental Democracy', Comparative Studies in Society and History 29.4

(October): 686-714
White, Gordon (1994) 'Civil Society, Democratization and Development (I): Clearing the Analytical Ground', Democratization 1.3 (Autumn): 375-90

Whitley, Richard (1994) Business Systems in East Asia: Firms, Markets and Societies, London: Sage Publications

Winckler, Edwin, A. (1992) 'Taiwan Transition?', in Tun-jen Cheng and Stephan Haggard (eds), Political Change in Taiwan, Boulder: Lynne Rienner: 221-59 